\title{
TEKNOLOGI PENGKAYAAN UNSUR-UNSUR N, P, Fe PADA RUMPUT LAUT Gracilaria verrucosa
}

\section{ENRICHMENT TECHNOLOGY OF N, P, Fe ELEMENTS TO SEAWEE Gracilaria verrucosa}

\author{
Eka Rosyida ${ }^{1}$, Enang H. Surawidjaja ${ }^{1}$, Sugeng H. Suseno ${ }^{2}$ dan Eddy Supriyono ${ }^{1}$ \\ ${ }^{1}$ Departemen Budidaya Perairan, Fakultas Perikanan, Institut Pertanian Bogor \\ ${ }^{2}$ Departemen Teknologi Hasil Perairan, Fakultas Perikanan, Institut Pertanian Bogor \\ Kampus IPB Dramaga, Bogor, Indonesia \\ e-mail : eka_ros@hotmail.com; enang_harris@yahoo.com; sug_thp@yahoo.com; eddy_supriyono@yahoo.com
}

Diterima tanggal: 19 Mei 2014, diterima setelah perbaikan: 20 November 2014, disetujui tanggal: 2 Desember 2014

\begin{abstract}
ABSTRAK
Penelitian ini bertujuan untuk mengkaji respon pertumbuhan Gracilaria verrucosa melalui teknologi pengkayaan N,P dan $\mathrm{Fe}$ sebagai unsur hara makro dan mikro ke dalam media budidaya. Metode penelitian menggunakan Rancangan Acak Lengkap (RAL) dengan 4 perlakuan dan 3 ulangan, yaitu tanpa pengkayaan nutrien/non-enriched (A), pengkayaan $\mathrm{N}(\mathrm{B})$, pengkayaan $\mathrm{N}+\mathrm{P}(\mathrm{C})$ dan pengkayaan $\mathrm{N}+\mathrm{P}+\mathrm{Fe}(\mathrm{D})$. Hasil penelitian menunjukkan pengkayaan $\mathrm{N}+\mathrm{P}+\mathrm{Fe}$ memberi pengaruh yang lebih tinggi terhadap pertumbuhan $G$. verrucosa dan berbeda secara signifikan dengan perlakuan lainnya $(\mathrm{p}<0.05)$. Disamping itu, klorofil dan konsentrasi $\mathrm{N}, \mathrm{P}, \mathrm{Fe}$ pada rumput laut juga terdeteksi lebih tinggi pada perlakuan tersebut. Dengan demikian dapat dikatakan teknologi pengkayaan dengan menggunakan kombinasi unsur hara makro (N,P) dan mikro $(\mathrm{Fe})$ dalam budidaya $G$. verrucosa dapat meningkatkan pertumbuhan secara signifikan sehingga dapat dipertimbangkan untuk diaplikasikan dalam budidaya rumput laut tersebut. Meskipun secara umum kadar dan karakteristik physico-kimia agar lebih baik pada perlakuan pengkayaan $\mathrm{N}+\mathrm{P}$, namun kadar agar dan gel strengthnya tidak berbeda dengan perlakuan pengkayaan $\mathrm{N}+\mathrm{P}+\mathrm{Fe}$.
\end{abstract}

Kata kunci: pengkayaan, pertumbuhan, klorofil, kadar agar, physico-kimia agar

\section{ABSTRACT}

This study was aimed to assess the growth response of Gracilaria verrucosa after enrichment of $N, P$ and Fe nutrients to the cultivation medium. The experiment was a complete randomized design with four treatments and in triplicate : non-enriched $(A)$; enriched with $N(B)$; enriched with $N+P(C)$; and enriched with $N+P+F e(D)$. The results showed $N+P+F e$ treatment affect significantly higher on growth of $G$. verrucosa and significantly different compare to others $(p<0.05)$. In addition, the seaweed chlorophyll content and $N, P, F e$ tissue retained were also high in those treatment. Hence, enrichment technology with the application of both macro $(N, P)$ and micro $(F e)$ elements would become considerable to the massive culture of seaweed. Eventhough in general the yield and properties of agar revealed a good performance in $N+P$ treatment, however, the agar content and gel strength was not different with $N+P+F e$ treatment.

Keywords: enrichment, growth, chlorophyll, agar yield, physico-chemistry of agar

\section{PENDAHULUAN}

Gracilaria verrucosa merupakan salah satu Rhodophyta penghasil polisakarida berupa agar yang sangat penting untuk berbagai industri, misalnya industri makanan, kertas, obat-obatan, dll. Kualitas alga merah ini selain ditekankan pada kandungan agar, juga dilihat dari kekuatan gel agar (agar gel strength) sesuai aplikasi dan penggunaannya secara komersial.
Di alam, salah satu faktor utama yang meregulasi pertumbuhan, reproduksi dan biokimia dari rumput laut adalah nutrien (Macler, 1986; Cole dan Sheath, 1990; Lobban dan Harrison, 1997), disamping faktor cahaya, pergerakan arus dan salinitas. De Boer (1981) menegaskan inorganic nutrien yang terdapat diperairan merupakan faktor pembatas yang sangat penting dalam produktivitas rumput laut. Hal ini diperkuat oleh hasil analisis yang menunjukkan ada sekitar 56 unsur nutrien yang terdapat dalam jaringan rumput laut tersebut. 
Sehubungan dengan hal tersebut, dalam media budidaya yang terkontrol telah banyak dilakukan penelitian teknologi pengkayaan nutrien untuk meningkatkan perumbuhan dan produksi makroalga tersebut.

Budidaya G.verrucosa di Indonesia telah berkembang cukup luas, dimana hasil budidaya dipengaruhi oleh kondisi yang bervariasi, seperti sumber air, iklim terutama terkait cahaya matahari/hujan, dll. Kondisi lingkungan yang berbeda antara satu daerah dengan daerah lainnya di Indonesia menyebabkan kualitas agar yang diperoleh dan harga dipasaran berbeda pula. Penerapan sistem budidaya rumput laut umumnya hanya mengandalkan air yang tersedia yang berada disekitar tambak, sementara pada sebagian pembudidaya ada pula yang menambahkan Nitrogen $(\mathrm{N})$ atau $\mathrm{N}+\mathrm{P}$ (phosphate)/NPK (kalium) untuk meningkatkan pertumbuhan Gracilaria. Penggunaan unsur hara mikro, misalnya $\mathrm{Fe}$, belum pernah diaplikasikan dalam budidaya Gracilaria, sedangkan unsur ini diketahui juga penting dalam pertumbuhan sel alga merah tersebut (Liu et al., 2000; Kakita dan Kamishima, 2007). Fe merupakan diantara unsur-unsur yang dibutuhkan oleh semua alga, dan secara umum berfungsi membantu aktivasi kerja enzim (De Boer, 1981). Oleh sebab itu, penelitian ini bertujuan untuk mengkaji respon pertumbuhan $G$. verrucosa melalui teknologi pengkayaan N,P dan $\mathrm{Fe}$ sebagai unsur hara makro and mikro ke dalam media budidaya. Hasil panen yang berasal dari perlakuan pengkayaan yang berbeda diharapkan dapat memberi gambaran tentang kualitas rumput laut dan agar yang dihasilkan.

\section{BAHAN DAN METODE}

\section{1. Tumbuhan Uji dan Kondisi Budidaya Gracilaria verrucosa}

Bibit Gracilaria verrucosa yang digunakan berasal dari tambak Desa Muara Gembong Bekasi. Budidaya dilakukan di Balai Pengembangan Budidaya Air Payau dan Laut (BPBAPL) Desa Pusakajaya Utara Kecamatan Cilebar, Karawang, Jawa Barat. Media budidaya adalah wadah persegi berukuran $2 \times 1,5 \times 0,80 \quad(\mathrm{~m})$ terbuat dari bambu dilapisi terpal plastik berwarna biru. Untuk menjamin adanya sinar matahari dan menghindari jatuhnya air hujan ke media budidaya, pada sekitar
1,5 $\mathrm{m}$ di atas media ditempatkan atap plastik bening transparan. Pada tiap wadah dipelihara rumput laut sebanyak $15 \mathrm{~kg}$ dengan volume air mencapai $1,5 \mathrm{~m}^{3}$. Sumber air berasal dari saluran yang digunakan untuk mengairi tambak di sekitar Balai.

Pengkayaan dilakukan seminggu sekali dan penggantian air dilakukan setiap 3 hari sekali (Truno, 1988) sebesar 50\% dari air media. Sebagai sumber $\mathrm{N}$ adalah Urea $(46 \% \mathrm{~N}), \mathrm{P}$ adalah SP $(36 \%$ $\mathrm{P}_{2} \mathrm{O}_{5}$ ) dan $\mathrm{Fe}$ adalah $\mathrm{FeCl}_{3 \cdot 6} \mathrm{H}_{2} \mathrm{O}$. Sebelum dan setelah periode budidaya, dilakukan pengukuran terhadap parameter kualitas air meliputi salinitas, suhu, oksigen terlarut (DO), dan $\mathrm{pH}$, serta pengukuran terhadap kandungan N,P, dan $\mathrm{Fe}$ dalam air media dan jaringan thallus rumput laut.

Penelitian pengkayaan ini merupakan bagian dari penelitian yang berkelanjutan, dimana data yang diinginkan adalah data pertumbuhan optimum untuk kemudian dibuat perlakuan lanjutan. Oleh sebab itu, penelitian ini dilakukan selama 2 minggu dengan pertimbangan rumput laut dapat mencapai pertumbuhan maksimumnya pada fase 2-3 minggu apabila budidaya dilakukan di bak terkontrol. Hal ini mengacu pada hasil-hasil penelitian sebelumnya, dimana Gracilaria sp. yang diberi urea dan TSP atau yang memanfaatkan limbah ekskresi udang pertumbuhannya meningkat di 2-3 minggu pertama, dan kemudian terus menurun hingga akhir penelitian (Patadjai, 1993; MarinhoSoriano et al. 2002; Sakdiah, 2009). Penelitian menggunakan konsentrasi nutrien yang terpilih pada percobaan pendahuluan, yaitu masing-masing $\mathrm{N}=50 \mathrm{ppm}, \mathrm{P}=5 \mathrm{ppm}$ dan $\mathrm{Fe}=2 \mathrm{ppm}$. Setelah 2 minggu pemeliharaan, rumput laut dipanen dan di timbang. Rumput laut segar diambil sebanyak masing-masing $50 \mathrm{~g}$ untuk tiap perlakuan untuk keperluan analisis klorofil, serta kandungan N,P,Fe thallus. Selanjutnya, sisa dari rumput laut dikeringkan untuk kemudian dianalisa kandungan agar dan karakteristik physico-kimia agarnya.

\subsection{Rancangan Percobaan}

Penelitian teknologi pengkayaan rumput laut menggunakan Rancangan Acak Lengkap (RAL) dengan 4 perlakuan dan masing-masing dibuat 3 ulangan, yaitu tanpa pengkayaan nutrien (A), pengkayaan $\mathrm{N}(\mathrm{B})$, pengkayaan $\mathrm{N}+\mathrm{P}$ (C) dan pengkayaan $\mathrm{N}+\mathrm{P}+\mathrm{Fe}$ (D) ke dalam air media budidaya. 


\subsection{Parameter Uji}

Untuk mengetahui laju pertumbuhan harian (Daily Growth Rate = DGR), perhitungan dilakukan berdasar Lignell et al. (1987) dalam Villanueva et al. (2009) sebagai berikut :

$\operatorname{DGR}(\mathrm{g}$ berat basah $) \quad=\left[\left(\mathrm{W}_{\mathrm{t}} / \mathrm{W}_{0}\right)^{1 / \mathrm{t}}-1\right] \times 100$

$$
\begin{array}{ll}
\text { dimana : } & \mathrm{W}_{\mathrm{t}}=\text { berat awal, } \\
& \mathrm{W}_{0}=\text { berat akhir, } \\
\mathrm{t} & =\text { waktu pada umur ke-t }
\end{array}
$$

Pengukuran klorofil dilakukan dengan menimbang sampel rumput laut seberat $0,5 \mathrm{~g}$ (berat basah), ditiriskan, lalu dilumatkan dengan mortar/penumbuknya dalam buffer solution phosphate $(\mathrm{pH}$ 6,5) untuk menghancurkan dinding sel. Hasil ekstraksi dituang ke dalam tabung centrifuge hingga $10 \mathrm{ml}$ lalu di-centrifuge selama 20 menit pada $2500 \mathrm{rpm}$ sehingga menghasilkan larutan yang mengandung pellet. Pellet kemudian direndam kembali di dalam $5 \mathrm{ml}$ aceton $80 \%$ (reagen analis) dan diaduk dengan homogenizer untuk mengekstraksi klorofil. Sample kemudian dicentrifuge kembali selama 20 menit pada 2500 rpm, lalu dibaca pada absorbance $664 \mathrm{~nm}$ untuk klorofil dan $710 \mathrm{~nm}$ larutan blanko.

Uji terhadap $\mathrm{N}$ dilakukan dengan menggunakan spektrofotometer pada kisaran 0,1 sampai 2,0 mg/L dengan menggunakan metode brusin dengan alat spektrofotometer pada panjang gelombang $410 \mathrm{~nm}$. Sedangkan penentuan kadar phosfat dengan metode spektrofotometer secara asam askorbat (SNI 06-6989.31-2005) pada kisaran kadar 0,0 mg $\mathrm{P} / \mathrm{L}$ sampai dengan 1,0 mg P/L. Untuk pengukuran $\mathrm{Fe}$ secara fotometris dengan sistem warna mengikuti hukum Beer pada panjang gelombang $510 \mathrm{~nm}$.

Agar diekstraksi dengan menimbang sebanyak 50 g rumput laut kering, dan direndam dalam larutan kaporit $0,25 \%$ selama $3 \times 24$ jam, dibilas dan dibersihkan, lalu direndam air tawar selama 3 jam. Sesudah itu, rumput laut direndam $\mathrm{H}_{2} \mathrm{SO}_{4} 0,1$ $\%$ selama 15 menit dan dicuci sampai bersih, lalu direndam air tawar kembali selama 15 menit. Selanjutnya, rumput laut dimasak dengan aquadest sebanyak $1500 \mathrm{~mL}$, disaring dan dituang ke dalam baki dan dikeringkan. Agar yang telah kering kemudian ditimbang. Kandungan agar dalam rumput laut kering (rendemen/yield) dihitung setelah di ekstraksi :

$$
\text { Rendemen }(\%)=\frac{\text { Berat Kadar agar }}{\text { Berat Rumput Laut }} \times 100 \%
$$

Analisis kekuatan gel dilakukan dengan cara menyiapkan larutan agar dalam konsentrasi 1,5\% (b/v), dipanaskan selama 10 menit sambil diaduk. Larutan panas dimasukkan ke dalam cetakan berdiameter $3 \mathrm{~cm}$ dengan tinggi $4 \mathrm{~cm}$. Larutan agar dibiarkan membentuk gel selama semalam. Pengukuran dilakukan dengan alat texture analyser dengan probe seluas $0,9123 \mathrm{~cm}^{2}$. Sampel diletakkan di bawah probe dan dibawah penekanan beban 97 g. Tinggi kurva diukur dengan menggunakan jangka sorong.

Analisis viscositas agar dilakukan dengan menggunakan viscometer Brookfield. Larutan agar dengan konsentrasi 1,5\% dipanaskan dalam bak air mendidih sambil di aduk secara teratur sampai suhu mencapai $75^{\circ} \mathrm{C}$, kemudian nilai viscositas dapat diketahui dengan pembacaan pada skala 1 sampai 100. Pembacaan dilakukan setelah 1 menit putaran penuh 2 kali untuk spindle no.1.

Uji kadar abu (AOAC, 2000) dilakukan dengan memasukkan sampel seberat 2-3 g ke dalam cawan kering yang telah diketahui bobotnya, kemudian dipijarkan dalam tanur $600^{\circ} \mathrm{C}$ sampai diperoleh abu berwarna keputihan.Cawan dan abu dimasukkan ke dalam desikator dan di timbang beratnya setelah dingin. Cawan dan abu dimasukkan ke dalam tanur selama 30 menit dan dimasukkan dalam desikator. Setelah dingin ditimbang kembali, dan perlakuan terus diulang hingga diperoleh berat abu yang konstan. Kadar abu ditentukan berdasarkan rumus:

$$
\text { Kadar abu }(\%)=\frac{\text { Berat } a b u(g)}{\text { Berat } \operatorname{sampel}(g)} \times 100 \%
$$

Uji kadar sulfat menggunakan sampel agar seberat $1 \mathrm{~g}$ dan dimasukkan ke dalam Erlenmeyer, ditambahkan $50 \mathrm{~mL} \quad \mathrm{HCl} \quad 0,2 \mathrm{~N}$, kemudian direfluks (6 jam). Larutan dipindahkan ke dalam gelas piala dan dipanaskan sampai mendidih, lalu ditambahkan $10 \mathrm{~mL} \mathrm{BaCl} 210 \%$ di atas pemanas air selama 2 jam. Endapan yang terbentuk disaring dengan kertas saring whattman 1 lalu dicuci dengan akuades mendidih hingga bebas klorida. 
Kertas saring dikeringkan dalam oven dan diabukan pada suhu $1000^{\circ} \mathrm{C}$. Abu didinginkan dalam desikator kemudian ditimbang. Perhitungan kadar sulfat adalah:

$$
\text { Kadar sulfat }(\%)=\frac{P \times 0,4116}{\text { Berat } \operatorname{sampel}(g)} \times 100 \%
$$

keterangan: 0,4116 $=$ massa atom relative $\mathrm{SO}_{4}$ dibagi massa atom relative $\mathrm{BaSO}_{4}$,

$\mathrm{P}=$ bobot endapan $\mathrm{BaSO}_{4}$

Kandungan air dalam agar di uji dengan memasukkan sampel $5 \mathrm{~g}$ ke dalam cawan yang telah dikeringkan dalam oven $100-102^{\circ} \mathrm{C}$ selama 15 menit dan telah diketahui bobotnya. Sampel dalam cawan dikeringkan selama 6 - 16 jam (suhu $100-102^{\circ} \mathrm{C}$ ). Cawan kemudian dipindahkan ke dalam desikator sampai bobotnya tetap kemudian ditimbang kembali. Kadar air (\%) diperoleh dari:

$$
\frac{\text { Berat sampel }(\text { awal }(g)-\text { kering }(g)}{\text { Berat sampel awal }(g)} \times 100 \%
$$

Data hasil penelitian diolah dengan analisis ragam (oneway anova, $p<0.05$ ), dilanjutkan dengan posthoc Fisher (LSD) menggunakan program MS Excel dan SPSS. Hubungan antar parameter dianalisis menggunakan pearson correlation.

\section{HASIL DAN PEMBAHASAN}

Teknologi pengkayaan berpengaruh nyata terhadap pertumbuhan $G$. verrucosa pada penelitian ini $(p<0.05)$. Laju pertumbuhan rumput laut dapat mencapai hingga $3.23 \pm 0.18 \%$ perhari setelah dibudidaya dalam bak-bak terkontrol (Gambar 1). Posthoc comparison menunjukkan bahwa pengkayaan $\mathrm{N}+\mathrm{P}+\mathrm{Fe}$ memberi pengaruh yang lebih tinggi terhadap pertumbuhan $G$. verrucosa dan berbeda secara signifikan dengan perlakuan lainnya $(\mathrm{p}<0.05)$.

Pengkayaan berbagai nutrien dalam media budidaya pada penelitian ini telah meningkatkan pertumbuhan $G$. verrucosa secara signifikan $(p<$ 0.05). Review oleh Briggs dan Smith (1993) menyebutkan bahwa pengkayaan nutrien yang dilakukan dengan menggunakan konsentrasi yang tepat menyebabkan Gracilaria mampu memanfaatkan nutrien tersebut untuk mendukung

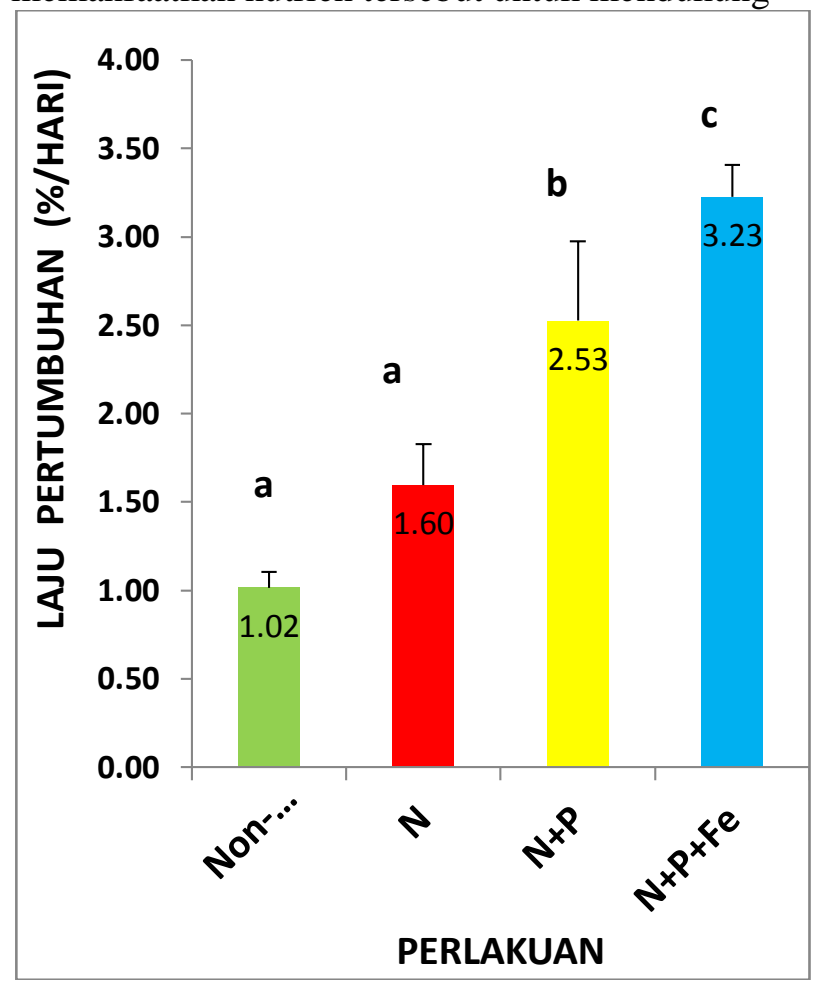

Gambar 1. Laju pertumbuhan harian Gracilaria verrucosa pada berbagai perlakuan.

Diagram yang ditandai dengan huruf yang sama menunjukkan tidak berbeda nyata $(p>0.05)$.

Figure 1. Daily growth rate of G.verrucosa in different treatments. Bars marked with the same letter indicate non-significant difference $(p>0.05)$

pertumbuhan maksimumnya. Di samping itu, secara umum kualitas air pada saat penelitian berada pada kisaran yang memenuhi persyaratan dalam mendukung pertumbuhan Gracilaria (DO: 3.3-3.8, $\mathrm{pH}: 7.7-8.3$, temperatur: $25-30^{\circ} \mathrm{C}$, and salinitas: $18-20 \%$ ).

Perlakuan pengkayaan yang berbeda pada media kultur juga berpengaruh signifikan terhadap kandungan klorofil $G$. verrucosa setelah dibudidaya $(p<0.05)$ (Gambar 2). Klorofil pada perlakuan $\mathrm{N}+\mathrm{P}+\mathrm{Fe}$ adalah yang tertinggi dibanding perlakuan lainnya dan berbeda nyata terhadap perlakuan lainnya $(p<0.05)$.

Ahmad et al. (2011) menyatakan kandungan klorofil rumput laut meningkat terhadap respon kandungan nitrogen dalam kolom air. Korelasi linier antara nutrien (utamanya total phosphor dan total nitrogen) dan klorofil telah ditunjukkan 
oleh beberapa peneliti sebelumnya (Brown et al., 2000). Penelitian ini memperkuat asumsi tersebut bahwa pemberian nutrien berpengaruh nyata terhadap kandungan klorofil rumput laut Gracilaria sp. (p<0,05). Di samping itu, pada penelitian ini didapatkan adanya korelasi

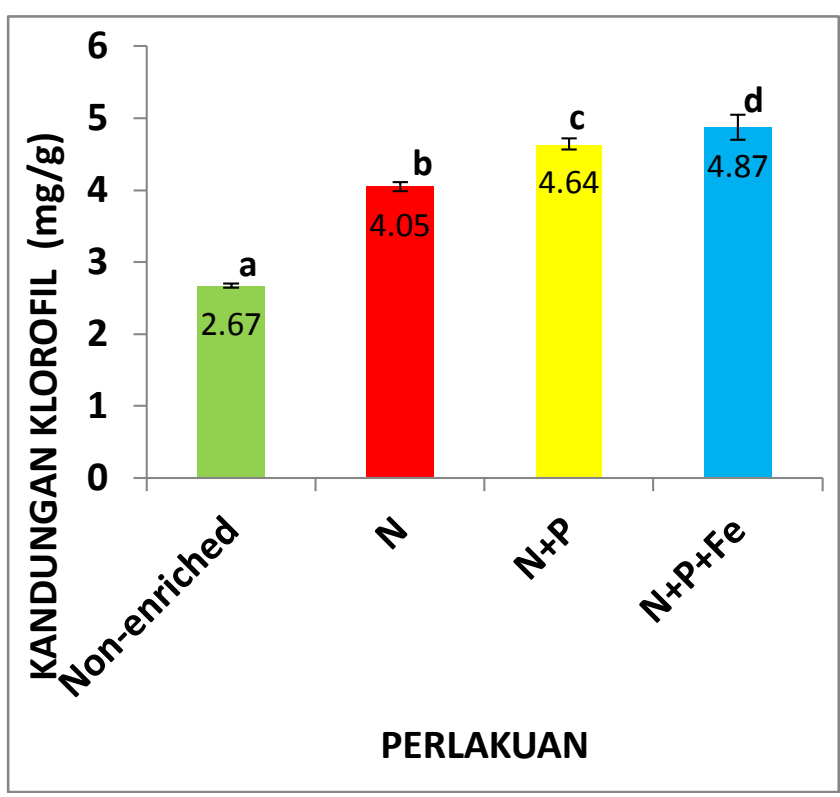

Gambar 2. Kandungan klorofil Gracilaria verrucosa setelah dibudidaya pada berbagai perlakuan. Diagram yang ditandai dengan huruf berbeda menunjukkan berbeda nyata $(p<0,05)$.

Figure 2. Chlorophyll content of $G$. verrucossa over cultivation in different treatments. Bars marked with different letter indicate significant difference $(p<0.05)$

yang kuat antara pertumbuhan dengan jumlah klorofil pada $G$. verrucosa $(r=0,71)$. Pengkayaan nutrien telah meningkatkan jumlah kandungan klorofil rumput laut dibanding perlakuan tanpa pengkayaan. Kandungan klorofil tertinggi terdeteksi pada alga yang dibudidaya dengan medium pengkayaan $\mathrm{N}+\mathrm{P}+\mathrm{Fe}$, dimana total nitrogen dalam jaringan thallusnya lebih tinggi dibanding perlakuan lainnya (Gambar 3). Keadaan serupa juga dilaporkan oleh Jones (1994), dimana ditemukan peningkatan klorofil $a$ seiring dengan peningkatan total $\mathrm{N}$ pada jaringan rumput laut Gracilaria. Hasil ini diperkuat oleh penelitian Liu et al. (2000) yang menyimpulkan bahwa pada semua tumbuhan, peningkatan konsentrasi total nitrogen dan fiksasi karbon pada proses fotosintesis terjadi secara bersamaan dan lebih dari $50 \% \mathrm{~N}$ dialokasikan pada kloroplas.

Aplikasi teknologi pengkayaan nutrien pada penelitian ini menunjukkan meningkatnya kandungan unsur-unsur hara yang ditambahkan, utamanya unsur $\mathrm{N}$, dimana kandungannya terdeteksi lebih tinggi pada rumput laut dengan perlakuan pengkayaan $\mathrm{N}+\mathrm{P}+\mathrm{Fe}$ dibanding dengan

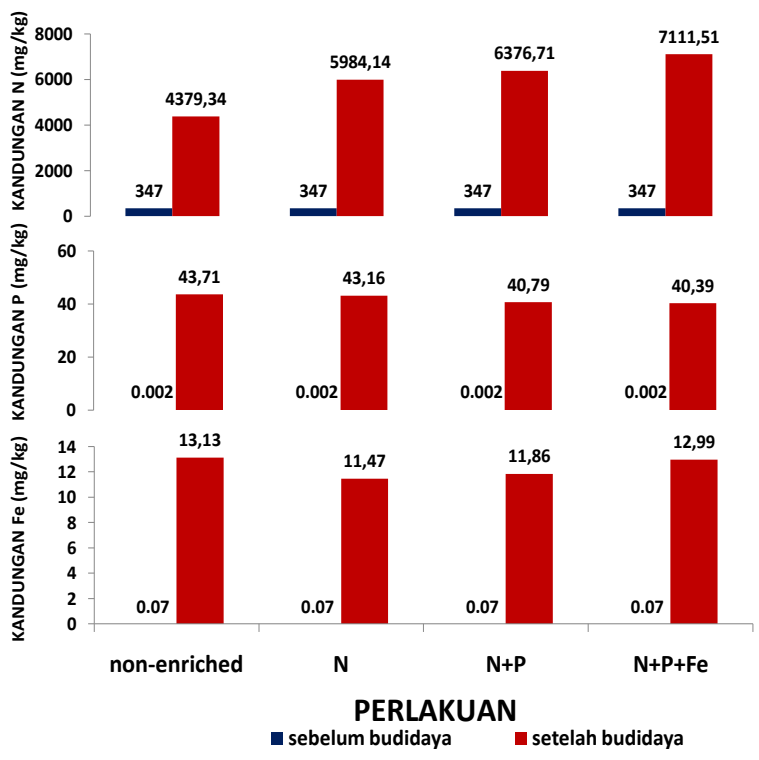

Gambar 3. Kandungan N,P,Fe pada jaringan thallus Gracilaria verrucosa pada berbagai perlakuan.

Figure 3. N, P, Fe tissue content of G.verrucosa in different treatments.

perlakuan lainnya. Kandungan $\mathrm{N}$ thallus yang tertinggi menunjukkan pertumbuhan rumput laut pada perlakuan tersebut lebih tinggi dibanding perlakuan lainnya. Hasil penelitian yang sama juga ditampilkan oleh Bird et al. (1981), dimana tingginya unsur $\mathrm{N}$ pada jaringan thallus berkorelasi dengan pertumbuhan rumput laut G. verrucosa. Pengkayaan zat besi (Fe), yang diberikan bersamasama dengan $\mathrm{N}$ dan $\mathrm{P}$ pada penelitian ini, kemungkinan telah membantu menstimulasi kerja enzim dalam proses respirasi dan fotosintesis. $\mathrm{Di}$ samping itu, dengan pengkayaan $\mathrm{Fe}$ memungkinkan metabolisme nitrogen dan asimilasi karbon meningkat sehingga pertumbuhan rumput laut menjadi lebih baik. Hal ini sesuai pendapat beberapa peneliti sebelumnya yang menyatakan bahwa selain sebagai co-faktor dalam mengaktivasi enzim (De Boer, 1981), unsur 
Fe juga berperan membantu metabolisme nitrogen dan asimilasi karbon ((Liu et al. 2000; Cordover, 2007) dalam proses pertumbuhan rumput laut. Oleh sebab itu, Liu et al. (2000) melaporkan bahwa sel alga membutuhkan lebih banyak $\mathrm{Fe}$ untuk mempertahankan pertumbuhannya. Pengkayaan zat besi yang memberikan pengaruh signifikan terhadap pertumbuhan G.verrucosa pada penelitian ini sejalan dengan hasil penelitian pada spesies Gracilaria lainnya sebagaimana dilaporkan oleh Liu et al. (2000) serta Kakita dan Kamishima (2007). Disamping itu, hasil penelitian ini juga menambah referensi terkait regulasi $\mathrm{Fe}$ dalam metabolisme nitrogen terhadap makroalga.

Penyerapan $\mathrm{Fe}$ dan phosphor, juga tinggi pada perlakuan non-enriched algae pada penelitian ini. Terbatasnya $\mathrm{N}$ pada medium perlakuan nonenriched menyebabkan rumput laut menyerap unsur lainnya yang tersedia di dalam medium kultur. Asumsi ini berdasar pada Briggs dan Funge-Smith (1993) yang menyatakan bahwa sebagai tumbuhan penyaring/ filter, Gracilaria mempunyai kapasitas untuk mereduksi nutrien yang banyak terdapat di saluran pembuangan atau dalam media dimana rumput laut tumbuh. Tetapi walaupun pada thallus terdeteksi kandungan $\mathrm{Fe}$ yang tinggi, rendahnya kandungan $\mathrm{N}$ telah menyebabkan rendahnya pertumbuhan karena $\mathrm{N}$ diketahui sebagai substansi utama yang dibutuhkan untuk pertumbuhan sel tumbuhan.

Review oleh Briggs dan Funge-Smith (1993) menunjukkan bahwa konsentrasi nutrien atau pengkayaan nutrien dapat meningkatkan pertumbuhan, fotosintesis, kandungan protein dan gel strengh agar dari Gracilaria. Pada penelitian ini, pengkayaan nutrien berpengaruh terhadap laju pertumbuhan, klorofil, dan juga gel strength, tetapi tidak berpengaruh terhadap kandungan agar. Hasil penelitian Bird et al. (1981), serta Lewis dan Hanisak (1996) menunjukkan tingginya kandungan $\mathrm{N}$ dalam jaringan thallus berbanding terbalik dengan kadar agar G.verrucosa. Hasil yang ditunjukkan dalam penelitian ini, meskipun perlakuan pengkayaan tidak berpengaruh nyata terhadap kadar agar, namun pada perlakuan pengkayaan $\mathrm{N}+\mathrm{P}+\mathrm{Fe}$, dimana jaringan thallusnya mengandung unsur $\mathrm{N}$ yang lebih tinggi dibanding perlakuan lainnya, kadar agarnya terdeteksi lebih rendah dibanding yang tidak diberi perlakuan pengkayaan.
Kandungan agar (rendemen) dan physico-kimia agar hasil budidaya terdeteksi bervariasi antar perlakuan (Tabel 1). Agar yang berasal dari perlakuan $\mathrm{N}+\mathrm{P}$ menunjukkan rendemen dan gel strength tertinggi dibanding perlakuan lainnya, tetapi kadar agar dan performa gel strength ini tidak berbeda dengan perlakuan $\mathrm{N}+\mathrm{P}+\mathrm{Fe}(p>0,05)$. Gel strength tertinggi pada perlakuan $\mathrm{N}+\mathrm{P}$ diikuti dengan rendahnya kadar sulfat dan abu agar dibanding perlakuan lainnya. Kadar sulfat dan abu dari perlakuan pengkayaan $\mathrm{N}+\mathrm{P}$ dapat dikategorikan memenuhi standar FAO, yaitu untuk sulfat dan abu masing-masing < 5\% dan maksimal $4 \%$. Pada penelitan ini, untuk semua perlakuan secara umum kadar sulfat menunjukkan hubungan terbalik dengan gel strength agar, dimana pada agar dengan kadar sulfat yang rendah memiliki gel strength yang tinggi. Sementara itu, kadar air terlihat lebih tinggi pada perlakuan dengan pengkayaan dibanding perlakuan tanpa pengkayaan, sedangkan viskositas adalah sebaliknya.

Tabel 1. Kadar agar dan karakteristik physico-kimia agar dari Gracilaria verrucosa hasil budidaya.

Table 1. Agar content and physico chemical properties of G.verrucosa after cultivation

\begin{tabular}{|c|c|c|c|c|c|c|}
\hline \multicolumn{7}{|c|}{ of G.verrucosa after cultivation } \\
\hline PERLAKUAN & $\begin{array}{l}\text { RENDEMEN } \\
(\%)\end{array}$ & $\begin{array}{l}\text { GEL } \\
\text { STRENGTH } \\
\left(\mathrm{g} / \mathrm{cm}^{2}\right)\end{array}$ & $\begin{array}{l}\text { VISCOSITAS } \\
\text { (CP) }\end{array}$ & $\begin{array}{l}\text { KADAR SULFAT } \\
(\%)\end{array}$ & $\begin{array}{c}\text { KADARABU } \\
(\%)\end{array}$ & $\begin{array}{c}\text { KADAR AIR } \\
(\%)\end{array}$ \\
\hline $\begin{array}{l}\text { Non-Enriched } \\
\end{array}$ & $10.20 \pm 2.23^{2}$ & $416.67 \pm 28.87^{2}$ & $4.50 \pm 0.28$ & $5.44 \pm 0.16$ & $5.28 \pm 0.17$ & $15.75 \pm 0.21$ \\
\hline$\overline{\mathrm{N}}$ & $9.33 \pm 2.25^{2}$ & $216.67 \pm 76.38^{b}$ & $4.22 \pm 0.31$ & $6.80 \pm 0.28$ & $4.75 \pm 0.13$ & $19.28 \pm 0.14$ \\
\hline$\overline{\mathrm{N}+\mathrm{P}}$ & $11.20 \pm 1.22^{\mathrm{s}}$ & $466.67 \pm 57.74^{36}$ & $4.40 \pm 0.14$ & $4.99 \pm 0.19$ & $3.34 \pm 0.30$ & $18.47 \pm 0.15$ \\
\hline$\overline{N+P+F e}$ & $9.93+1.86^{3}$ & $383.33+85.05^{\mathrm{c}}$ & $4.35 \pm 0.07$ & $5.95 \pm 0.21$ & $4.56 \pm 0.41$ & $18.25 \pm 0.35$ \\
\hline
\end{tabular}

* Angka-angka yang diikuti superscript yang berbeda pada kolom yang sama menunjukkan perbedaan nyata $(p<0,05)$.

Superscript marked with different letter indicate significant different $(p<0.05)$

Sebagaimana penjelasan di atas, pengkayaan dengan $\mathrm{N}+\mathrm{P}+\mathrm{Fe}$ menunjukkan pertumbuhan yang lebih tinggi. Sedangkan, secara umum baik kuantitas maupun kualitas agar yang diperoleh dari perlakuan pengkayaan $\mathrm{N}+\mathrm{P}$ lebih tinggi. Namun demikian, kadar agar dan gel strength yang diperoleh dari perlakuan ini tidak berbeda dengan perlakuan pengkayaan $\mathrm{N}+\mathrm{P}+\mathrm{Fe}$, sehingga dapat dikatakan bahwa selain dapat meningkatkan produktivitas, pengkayaan dengan $\mathrm{N}+\mathrm{P}+\mathrm{Fe}$ dalam penelitian ini juga menghasilkan rumput laut dengan kadar agar dan performa gel strength yang cukup baik. Sejauh ini, belum ada studi terkait 
mekanisme regulasi $\mathrm{Fe}$ terhadap kualitas agar. Oleh sebab itu, dibutuhkan suatu studi yang lebih detail dimasa yang akan datang, sehingga keterkaitan $\mathrm{Fe}$ sebagai nutrien dalam media budidaya dengan kualitas agar yang dihasilkan oleh rumput laut dapat lebih dipahami.

\section{KESIMPULAN DAN SARAN}

Teknologi pengkayaan nutrien dengan menggunakan kombinasi unsur hara makro (N,P) dan mikro $(\mathrm{Fe})$ dalam budidaya Gracilaria verrucosa dapat meningkatkan laju pertumbuhan 2 kali lebih cepat dibanding tanpa pengkayaan, sehingga dapat dipertimbangkan untuk diaplikasikan dalam budidaya rumput laut. Meskipun secara umum perlakuan pengkayaan $\mathrm{N}+\mathrm{P}$ memiliki karakteristik physico-kimia agar yang lebih baik, namun kadar agar dan gel strengthnya tidak berbeda dengan perlakuan pengkayaan $\mathrm{N}+\mathrm{P}+\mathrm{Fe}$.

\section{UCAPAN TERIMA KASIH}

Penulis mengucapkan terima kasih kepada Dirjen Pendidikan Tinggi, Kementerian Pendidikan \& Kebudayaan Republik Indonesia dan Dinas Kelautan \& Perikanan Provinsi Sulawesi Tengah atas dukungan dana pada penelitian ini. Ucapan terima kasih juga ditujukan kepada Balai Pengembangan Budidaya Air Payau dan Laut (BPBAPL) Karawang, Jawa Barat atas fasilitas selama penelitian.

\section{DAFTAR PUSTAKA}

Ahmad, S.H., Surif, M., Wan Omar, W.M., Rosli, MN., \& Nor, A.R. (2011). Nutrient uptake, growth and chlorophyll content of green seaweed, Ulva reticulata: Response to Different Source of Inorganic Nutrients. UMTAS.

AOAC (Association of Official Analytical Chemists). 2000. Official methods of analysis $\left(17^{\text {th }}\right.$ ed.). Association of Official Analytical Chemists, Inc. Gaithersburg, Maryland, USA.

Bird, K.T., Hanisak, M.D., \& Ryther, J. (1981). Chemical quality and production of agars extracted from $G$. tikvahiae grown in different nitrogen enrichment and condition. Botanica Marina, 24, 441-444.

Briggs, M.R.P., \& Funge-Smith, S.J. (1993). Macroalga in aquaculture: an overview and their possible roles in shrimp culture. Paper presented at the Conference on Marine Biotechnology in the Asia Pacific Region, Bangkok, Thailand.

Brown, C.D., Hoyer, M.V., Bachmann, R.W., \& Canfield, Jr.D.E. (2000). Nutrientchlorophyll relationships: an evaluation of empirical nutrient-chlorophyll models using Florida and north-temperate lake data. Can. J. Fish. Aquat. Sci. 57, 15741583.

Cole, K.M., \& Sheath, R.G. (1990). Biology of the red algae. Cambridge University Press. Cambridge.

Cordover, R. (2007). Seaweed agronomy: cropping in inland saline groundwater evaporation basins. A report for the Rural Industries Research and Development Cooperation. Australia Government. $60 \mathrm{pp}$

De Boer, JA. (1981). Nutrients. In C.S. Lobban, \& M.J. Wynne (Eds.). The Biologi of Seaweed (Volume 17). Univ.of california Press, Barkeley and Los Angeles.

Jones, A.B. (1994). Influence of nitrogen source and availability on amino acids, pigments and tissue nitrogen of gracilaria edulis (rhodophyta). Unpublish master's thesis, Dept.of Botany, Univ.of Queensland. Australia.

Kakita, H., \& Kamishima, H. (2007). Effects of environmental factors and metal ions on growth of the red alga Gracilaria chorda Holmes (Gracilariales, Rhodophyta). Proceedings of the International Seaweed Symposium 18, 243-248.

Lewis, R.J. \& Hanisak, M.D. (1996). Effect of phosphate and nitrate supply on productivity, agar content and physical properties of agar of Gracilaria Strain G16S. J. Appl.Phycol. 8, 41-49

Liu, J.W., Dong, S.L., Liu, X.Y., \& Ma, S. (2000). Responses of the macroalga Gracilaria tenuistipitata var.liui (Rhodophyta) to iron stress. Journal of Applied Phycology 12, 605-612. 
Lobban, C.S \& Harrison, P.J. (1997). Seaweed ecology and physiology. Cambridge University Press. Cambridge.

Macler, B.A. (1986). Regulation of carbon flow by nitrogen and light in the red algae, Gelidium coulteri. Plant.Physiol. 82, 136141.

Marinho-Soriano, E., Morales, C., \& Moreira, W.S.C. (2002). Cultivation of Gracilaria (Rhodophyta) in shrimp ponds effluents in Brazil. Aquaculture Research 33, 10811086.

Patadjai, R.S. (1993). Pengaruh pupuk TSP terhadap pertumbuhan dan kualitas rumput laut Gracilaria gigas Harv. Unpublish master's thesis, Program Pascasarjana Institut Pertanian Bogor. Bogor.

Sakdiah, M. (2009). Pemanfaatan limbah nitrogen udang Vaname (Litopenaeus Vannamei) oleh rumput laut (Gracilaria verrucosa) pada sistem budidaya polikultur. Unpublish master's thesis, Program Pascasarjana Institut Pertanian Bogor. Bogor.

Truno, G.C. (1988). Manual on seaweed culture, "pond culture of Caulerpa and pond culture of Gracilaria. ASEAN/SF/1988/Manual No.3.

Villanueva, R.D., Hilliou, L., \& Sousa-Pinto, I. (2009). Short communication: postharvest culture in the dark: an eco-friendly alternative to alkali treatment for enhancing the gel quality of k/t- hybrid carrageenan from Chondrus crispus (Gigartinales, Rhodophyta). Bior. Tech, 100, 2633-2638. 